\title{
Erdheim-Chester disease among neuroinflammatory syndromes: the case for precision medicine
} Macarena I. de la Fuente, MD, Marc K. Rosenblum, MD, Eli L. Diamond, MD, Viviane S. Tabar, MD, and
Antonio Omuro, MD

Neurol Neuroimmunol Neuroinflamm 2020;7:e686. doi:10.1212/NXI.0000000000000686

Erdheim-Chester disease (ECD) is a rare, non-Langerhans histiocytosis characterized by xanthogranulomatous infiltration typically affecting long bones, cardiovascular system, retroperitoneum, and lung, and that involves the CNS in $25 \%-50 \%$ of patients (table). ${ }^{1,2}$ Historically, establishing the diagnosis has been challenging, particularly in the absence of systemic abnormalities. Recent genomic studies have uncovered that approximately $50 \%$ of ECD tissue samples harbor a mutation in the BRAF gene, ${ }^{3}$ termed $B R A F^{V 600 E}$, and that pointed to a neoplastic, rather than inflammatory, nature of the disease. ${ }^{4,5}$

We describe a case of ECD with isolated CNS presentation emphasizing the diagnostic challenges and how a precision medicine approach provided a path to successful treatment.

\section{Clinical case}

A 51-year-old right-handed man presented with a 3-month history of diplopia and falls. Neurologic examination revealed right VI nerve palsy and mildly ataxic gait, with no other findings. A brain MRI revealed multifocal FLAIR hyperintensities mainly in the posterior fossa, with nodular enhancement (figure 1, A and B). Extensive workup was unrevealing (lactate dehydrogenase, erythrocyte sedimentation rate, B2-microglobulin, angiotensin-converting enzyme, CSF analysis with flow cytometry, spine MRI, HIV, syphilis, and rheumatologic/inflammatory panels). Whole body fluorodeoxyglucose-positron emission tomography showed minor increased uptake within the pons and no systemic abnormalities. CT of the legs was normal.

The patient underwent stereotactic needle biopsy of a leading cerebellar lesion. Pathology showed fragments of normal cerebellum and no mutations on next-generation targeted sequencing of 422 genes (NGS). High-dose steroids were tried without clinical improvement. ECD was considered but felt unlikely because of the absence of systemic involvement.

Three weeks after corticosteroid tapering, an open biopsy was performed, but pathology and NGS were again unrevealing. Given mild but continuous worsening of symptoms, a decision was made to perform a third cerebellar biopsy. Pathology showed nongranulomatous lymphohistiocytic infiltrates, with CD3-labeling $\mathrm{T}$ cell infiltrates, no loss of pan- $T$ antigen expression, and rare $B$ cells. A very large number of CD 163-labeling, CD1a/ Langerin-negative mononuclear elements were present. Findings were reviewed by 3 pathologists; the possibility of an infection was raised, and infectious diseases genomic studies suggested. However, given normal CSF, and on discussions with an experienced pathologist (M.R.), tissue was prioritized for genomic studies focusing on neoplastic etiologies and ECD. Immunohistochemistry for $B R A F^{V 600 E}$ mutation and RNA sequencing
Correspondence

Dr. Omuro

antonio.omuro@yale.edu

From the Department of Neurology, Sylvester Comprehensive Cancer Center (M.I.d.I.F., A.O.), University of Miami, Miami, FL; and Department of Pathology (M.K.R.), Department of Neurology (E.L.D.), and Department of Neurosurgery (V.S.T.), Memorial Sloan Kettering Cancer Center, New York, NY.

Go to Neurology.org/NN for full disclosures. Funding information is provided at the end of the article.

The Article Processing Charge was funded by Yale Cancer Center.

This is an open access article distributed under the terms of the Creative Commons Attribution-NonCommercial-NoDerivatives License 4.0 (CC BY-NC-ND), which permits downloading and sharing the work provided it is properly cited. The work cannot be changed in any way or used commercially without permission from the journal. 
Table Clinical manifestations of ECD

\begin{tabular}{|c|c|c|c|}
\hline Organ involved & Manifestation & Incidence, \% & Comment \\
\hline Bone & Long bone osteosclerosis & $80-95 \%$ & Presents with pain or asymptomatic. \\
\hline \multirow[t]{4}{*}{ Cardiovascular } & Periaortic infiltration & $46-62 \%$ & Usually asymptomatic \\
\hline & Right atrium pseudotumor & $9-57 \%$ & \\
\hline & Coronary infiltration & $27 \%$ & $\begin{array}{l}\text { Risk for coronary stenosis and } \\
\text { myocardial infarction }\end{array}$ \\
\hline & Pericardial involvement & $10-31 \%$ & Risk for tamponade \\
\hline Pulmonary & $\begin{array}{l}\text { Involvement of pleura, lung } \\
\text { parenchyma or both }\end{array}$ & $25-50 \%$ & $\begin{array}{l}\text { Asymptomatic or manifest as dyspnea } \\
\text { and/or cough }\end{array}$ \\
\hline Retroperitoneum & Mass-like, perirenal infiltrative lesion & $58-65 \%$ & "Hairy kidneys" \\
\hline \multirow[t]{5}{*}{ Central nervous system } & Periorbital involvement & $22-27 \%$ & Exophthalmos \\
\hline & CNS involvement & $37-38 \%$ & $\begin{array}{l}\text { Cognitive impairment, neuropsychiatric } \\
\text { and pyramidal syndrome }\end{array}$ \\
\hline & Pituitary involvement & $28-47 \%$ & Central diabetes insipidus \\
\hline & Cerebellar involvement & $17 \%$ & \\
\hline & Dura involvement & & $\begin{array}{l}\text { Differential diagnosis with } \\
\text { meningioma }\end{array}$ \\
\hline
\end{tabular}

Abbreviation: $\mathrm{ECD}=$ Erdheim-Chester disease.

panel (ARCHER) showed no abnormalities (no BRAF/ KIAA gene fusions). NGS was initially reported as negative, but review of results and comparison of pathology accession numbers indicated DNA had been inadvertently extracted using tissue from a previous biopsy. NGS was repeated using the correct tissue and finally demonstrated a $B R A F^{V 600 E}$ mutation, as well as mutations in CHEK2, DOT1L, KDMSA, and MSH6 and deletions in ROS1 and ATXN2. The integrated pathology diagnosis was ECD. The disease course timeline was summarized in figure 2 .

Further staging included normal echocardiogram and cardiac MRI; repeat fluorodeoxyglucose-positron emission tomography/CT showed right knee mild hypermetabolism, questioning osseous involvement. Treatment with vemurafenib, an Food and Drug Administration-approved drug for ECD, was considered. However, based on the literature on $B R A F^{V 600 E}$ melanoma suggesting improved efficacy and decreased toxicity with combined BRAF and MEK1/2 inhibition, a regimen with dabrafenib and trametinib was favored. After insurance denial and a successful appeal process supported by the genomic findings, treatment was initiated, resulting in significant and early clinical and radiographic improvement (figure $1, \mathrm{C}$ and $\mathrm{D}$ ). The patient was still in remission $18+$ months later.

\section{Discussion}

This report illustrates how a combination of precision medicine, perseverance, and clinical judgment may result in successful diagnoses and treatments of rare diseases. Although this patient's MRI did show findings suggestive of ECD, these are not pathognomonic and differential was broad. The absence of systemic findings further confounded the diagnosis.

Two biopsies and NGS were negative, and it would be tempting to categorize this case among unspecified CNS inflammatory disorders. However, the mismatch between MRI suggesting an active process and histology showing no signs of active inflammatory or neoplastic diseases suggested biopsies and NGS were not representative of the ongoing process. The lack of response to corticosteroids was another red flag for an inflammatory disease or CNS lymphoma diagnosis, prompting a third, and eventually representative biopsy. Histology remained inconclusive after multiple reviews, but genetic analysis finally provided the crucial missing information. Interestingly, $B R A F^{V 600 E}$ was negative by immunohistochemistry. ${ }^{6,7}$ IHC is a sensitive and specific tool for detection of BRAF-V600E. However, negative or low staining cases should undergo genetic analysis, based on clinical and histopathologic features. It is also noteworthy that the first 2 gene sequencing attempts were negative because the tissue was not representative of the active process, containing normal cerebellum and no neoplastic cells to allow for detection of this somatic mutation. ${ }^{8}$

The genomic findings provided a path for utilization of dabrafenib and trametinib, possibly a better treatment of ECD than single-agent vemurafenib, but that is not Food and Drug Administration-approved, with only one treated 


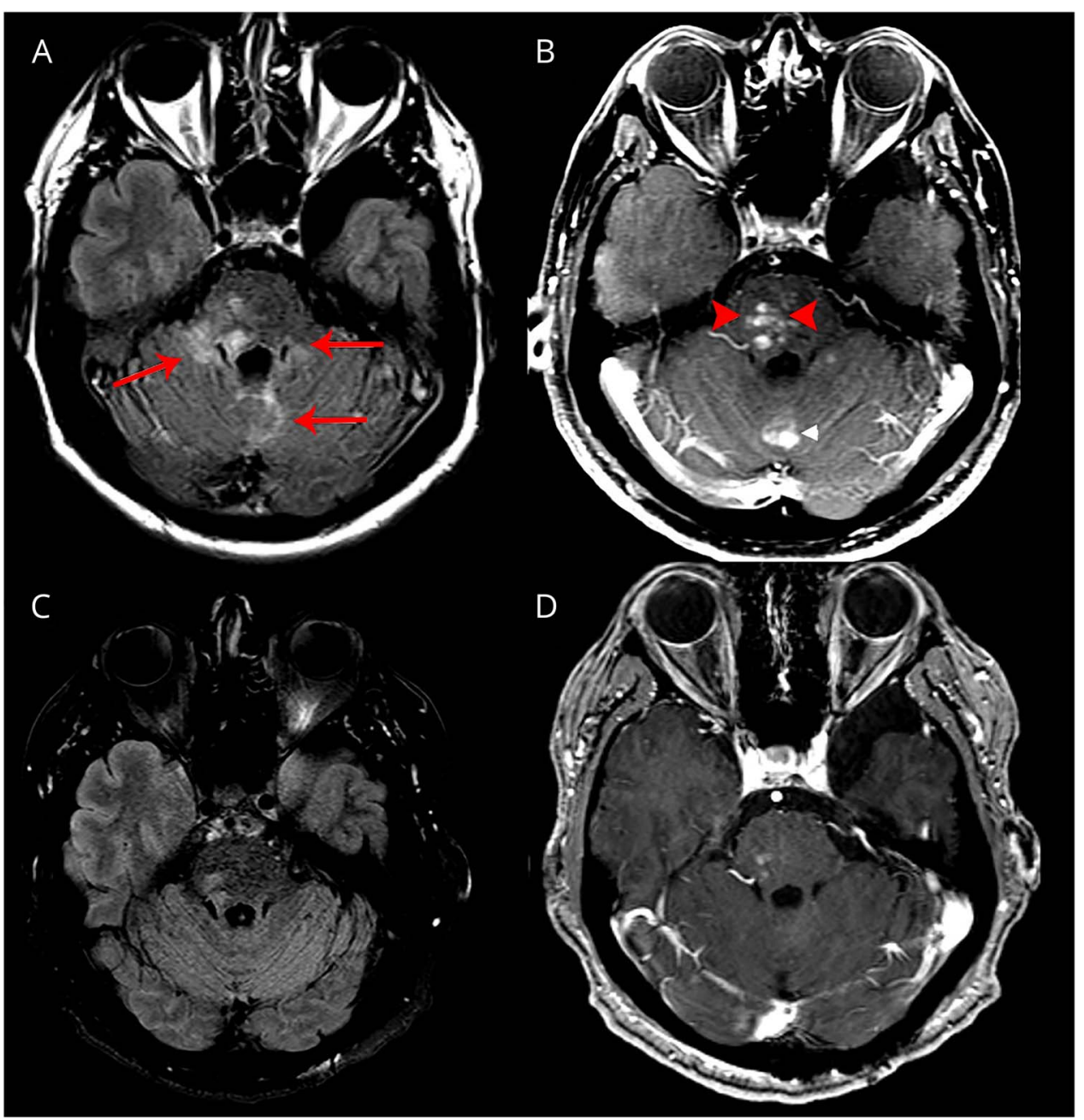

(A and B) Baseline MRI. Axial FLAIR (A) sequence showing FLAIR signal hyperintensity lesions in the pons, middle cerebellar peduncles, and cerebellum (arrows), with corresponding solid enhancement on T1 postcontrast images (arrow heads). A follow-up MRI (C and D) performed 10 weeks into treatment, showing near complete resolution of the lesions. patient reported in the literature. ${ }^{2}$ We provide a second case successfully treated off-label with this combination. Overall, our patient illustrates how precision medicine can result in successful diagnosis and therapies for previously untreatable conditions, although clinical judgment remains irreplaceable for realizing the full potential of emerging technologies.

Figure 2 Disease course timeline

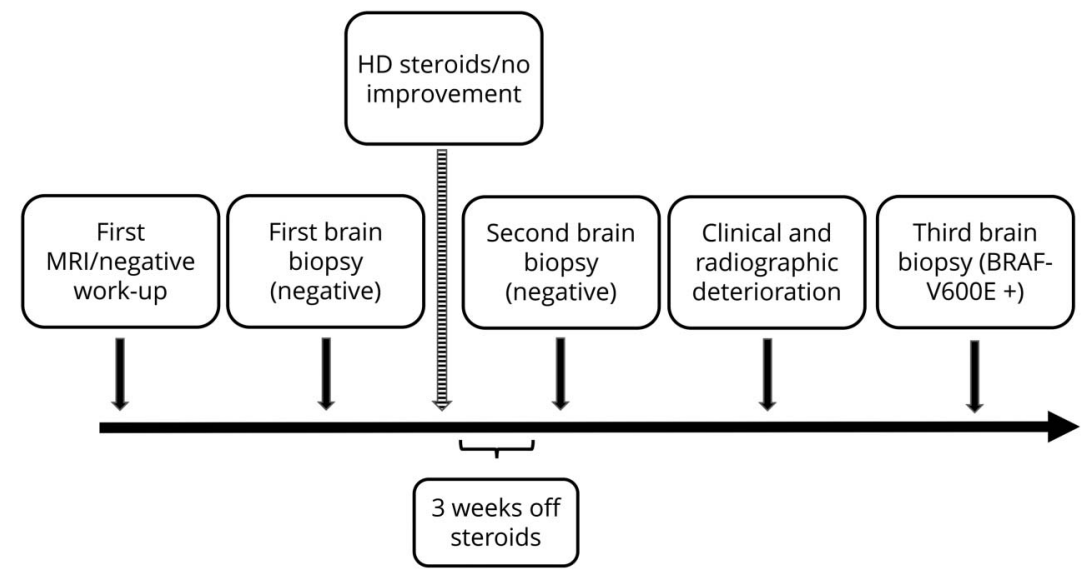




\section{Study funding}

Study sponsor: Sylvester Comprehensive Cancer Center and Yale Brain Tumor Center.

\section{Disclosure}

M.I. de la Fuente served as a member on an ad hoc scientific advisory board for Puma Biotechnology, Agios Pharmaceuticals, and Forma Therapeutics and as a consultant for Foundation Medicine. M.K. Rosenblum has nothing to disclose. E.L. Diamond has nothing to disclose. V.S. Tabar is a scientific cofounder of Blue Rock Therapeutics and receives research support from the same. She is a scientific advisor for Robeauté. A. Omuro served as a member on an ad hoc scientific advisory board for BTG and Merck. Go to Neurology. org/NN for full disclosures.

\section{Publication history}

Received by Neurology: Neuroimmunology \& Neuroinflammation December 16, 2019. Accepted in final form January 30, 2020.

\section{Appendix Authors}

\begin{tabular}{lll}
\hline Name & Location & Contribution \\
\hline $\begin{array}{l}\text { Macarena I. } \\
\text { de la Fuente, } \\
\text { MD }\end{array}$ & $\begin{array}{l}\text { University of } \\
\text { Miami }\end{array}$ & $\begin{array}{l}\text { Data acquisition; drafting/revising } \\
\text { the manuscript; analysis or } \\
\text { interpretation of the data }\end{array}$ \\
\hline $\begin{array}{l}\text { Marc K. } \\
\text { Rosenblum, } \\
\text { MD }\end{array}$ & $\begin{array}{l}\text { Mettering Cancer } \\
\text { Center }\end{array}$ & $\begin{array}{l}\text { Data acquisition; drafting/revising } \\
\text { the manuscript; analysis or } \\
\text { interpretation of the data }\end{array}$ \\
& &
\end{tabular}

Appendix (continued)

\begin{tabular}{lll}
\hline Name & Location & Contribution \\
\hline $\begin{array}{l}\text { Eli L. } \\
\text { Diamond, MD }\end{array}$ & $\begin{array}{l}\text { Memorial Sloan- } \\
\text { Kettering Cancer } \\
\text { Center }\end{array}$ & $\begin{array}{l}\text { Drafting/revising the manuscript; } \\
\text { analysis or interpretation of the } \\
\text { data }\end{array}$ \\
\hline $\begin{array}{l}\text { Viviane S. } \\
\text { Tabar, MD }\end{array}$ & $\begin{array}{l}\text { Memorial Sloan- } \\
\text { Kettering Cancer } \\
\text { Center }\end{array}$ & Data acquisition \\
\hline $\begin{array}{l}\text { Antonio } \\
\text { Omuro, MD }\end{array}$ & $\begin{array}{l}\text { Yale Brain Tumor } \\
\text { Center }\end{array}$ & $\begin{array}{l}\text { Data acquisition; drafting/revising } \\
\text { the manuscript; study concept or } \\
\text { design; analysis or interpretation } \\
\text { of the data }\end{array}$ \\
\hline
\end{tabular}

\section{References}

1. Diamond EL, Dagna L, Hyman DM, et al. Consensus guidelines for the diagnosis and clinical management of Erdheim-Chester disease. Blood 2014;124:483-492.

2. Al Bayati A, Plate T, Al Bayati M, Yan Y, Lavi ES, Rosenblatt JD. Dabrafenib and trametinib treatment for erdheim-chester disease with brain stem involvement. Mayo Clin Proc Innov Qual Outcomes 2018;2:303-308.

3. Haroche J, Charlotte F, Arnaud L, et al. High prevalence of BRAF V600E mutations in Erdheim-Chester disease but not in other non-Langerhans cell histiocytoses. Blood 2012;120:2700-2703.

4. Haroche J, Cohen-Aubart F, Emile JF, et al. Dramatic efficacy of vemurafenib in both multisystemic and refractory Erdheim-Chester disease and Langerhans cell histiocytosis harboring the BRAF V600E mutation. Blood 2013;121:1495-1500.

5. Cohen Aubart F, Emile JF, Carrat F, et al. Targeted therapies in 54 patients with Erdheim-Chester disease, including follow-up after interruption: the LOVE study. Blood 2017;130:1377-1380.

6. Breton $\mathrm{Q}$, Plouhinec H, Prunier-Mirebeau D, et al. BRAF-V600E immunohistochemistry in a large series of glial and glial-neuronal tumors. Brain Behav 2017;7:e00641.

7. Anwar MA, Murad F, Dawson E, Abd Elmageed ZY, Tsumagari K, Kandil E. Immunohistochemistry as a reliable method for detection of BRAF-V600E mutation in melanoma: a systematic review and meta-analysis of current published literature. I Surg Res 2016;203:407-415.

8. Estrella JS, Tetzlaff MT, Bassett RL Jr, et al. Assessment of BRAF V600E status in colorectal carcinoma: tissue-specific discordances between immunohistochemistry and sequencing. Mol Cancer Ther 2015;14;2887-2895. 


\section{Neurology \\ Neuroimmunology \& Neuroinflammation}

Erdheim-Chester disease among neuroinflammatory syndromes: the case for precision medicine

Macarena I. de la Fuente, Marc K. Rosenblum, Eli L. Diamond, et al.

Neurol Neuroimmunol Neuroinflamm 2020;7;

DOI 10.1212/NXI.0000000000000686

This information is current as of March 2, 2020

Neurol Neuroimmunol Neuroinflamm is an official journal of the American Academy of Neurology.

Published since April 2014, it is an open-access, online-only, continuous publication journal. Copyright

Copyright $\odot 2020$ The Author(s). Published by Wolters Kluwer Health, Inc. on behalf of the American

Academy of Neurology.. All rights reserved. Online ISSN: 2332-7812.

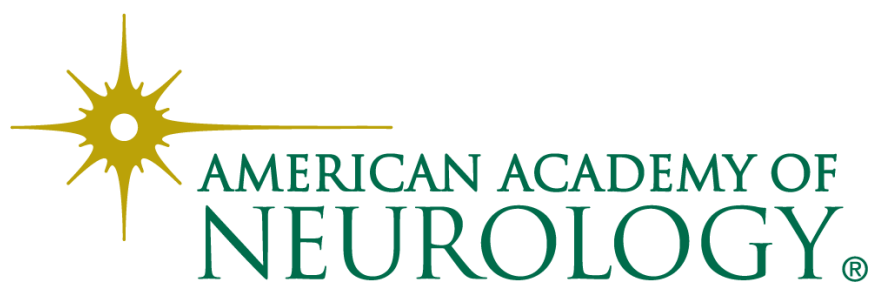




\section{Updated Information \& Services}

References

Subspecialty Collections

Permissions \& Licensing

\section{Reprints}

including high resolution figures, can be found at:

http://nn.neurology.org/content/7/3/e686.full.html

This article cites 8 articles, 5 of which you can access for free at: http://nn.neurology.org/content/7/3/e686.full.html\#\#ref-list-1

This article, along with others on similar topics, appears in the following collection(s):

All Clinical Neurology

http://nn.neurology.org//cgi/collection/all_clinical_neurology

All Medical/Systemic disease

http://nn.neurology.org//cgi/collection/all_medical_systemic_disease

All Oncology

http://nn.neurology.org//cgi/collection/all_oncology

Chemotherapy-tumor

http://nn.neurology.org//cgi/collection/chemotherapytumor

Primary brain tumor

http://nn.neurology.org//cgi/collection/primary_brain_tumor

Information about reproducing this article in parts (figures,tables) or in its entirety can be found online at:

http://nn.neurology.org/misc/about.xhtml\#permissions

Information about ordering reprints can be found online:

http://nn.neurology.org/misc/addir.xhtml\#reprintsus

Neurol Neuroimmunol Neuroinflamm is an official journal of the American Academy of Neurology.

Published since April 2014, it is an open-access, online-only, continuous publication journal. Copyright

Copyright $\odot 2020$ The Author(s). Published by Wolters Kluwer Health, Inc. on behalf of the American

Academy of Neurology.. All rights reserved. Online ISSN: 2332-7812.

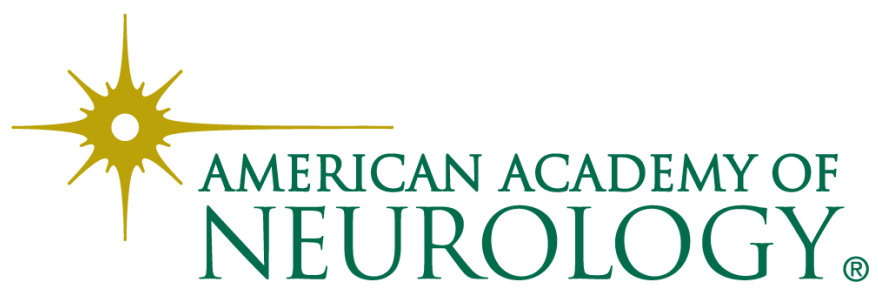

